\title{
PROFILE OF STUDENT MATHEMATICAL CONNECTION ABILITIES IN UNDERSTANDING MATHEMATICAL CONCEPTS IN TERMS OF GENDER
}

\author{
Amalia Fitrianingsih $^{1)}$, Lilik Ariyanto $^{2)}$, Ida Dwijayanti ${ }^{3)}$ \\ ${ }^{1,2,3}$ Universitas PGRI Semarang. Jl. Dr. Cipto-Lontar No.1 Semarang, Indonesia. \\ E-mail : amaliafitrianingsih3@gmail.com¹, lilikariyanto@upgris.ac.id², idadyana@gmail.com³
}

\begin{abstract}
According to Permendikbud number 58 in 2014, one of the objectives of learning mathematics is to be able to understand mathematical concepts. In understanding mathematical concepts, of course, students need mathematical connection skills to connect between concepts and real life. There are many differences between men and women, especially ways of thinking, perspective, and mathematical abilities. For this reason researchers want to know how the profile of students' mathematical counseling ability in understanding mathematical concepts in terms of gender. This study aims to determine the profile of students' mathematical connection abilities in understanding mathematical concepts in terms of gender. This research is a qualitative descriptive study. The research subjects were 3 male students and 3 female students of class VII MTs N 1 Kudus who were selected based on the daily score of the medium group. Data collection techniques in the form of written tests and interviews. The validity of the data uses source triangulation. The results of this study are: a) Profile of male students' mathematical connection ability in understanding mathematical concepts that is at the stage of interpreting, male students interpret by looking at the length of their sides. At the stage of imitating by looking around objects. In the classifying stage by looking at the number of sides. At the stage summarize by remembering what is in the book and see the shape. At the stage of concluding, connect with the characteristics. At the comparing stage, by looking at the sides and corners, but unable to relate to other material. At the explaining stage, with your own thoughts by looking at the shape. b) Profile of female students' mathematical connection abilities in understanding mathematical concepts that is at the stage of interpreting, female students interpret images because of their desires. At the example stage, by looking around objects. In the classifying stage, only mention the name of the object. At the stage of summarizing, remembering what is in the book and what the teacher teaches. At the stage of concluding, connect with the characteristics. At the comparing stage, by looking at sides and angles and also linking with other material. At the explaining stage, remember what is in the book.
\end{abstract}

Keywords: Mathematical Connection, Understanding Concepts, Gender

\section{PENDAHULUAN}

Perkembangan pengetahuan matematika melibatkan proses mengambil konsep-konsep baru dan membuat hubungan antara berbagai bagian pengetahuan yang telah terwakili secara internal (Lapp, dkk 2010:2). Matematika juga saling berkaitan satu sama lain seperti pendapat Romli (2016:145) yang mendefinisikan matematika merupakan ilmu yang terstruktur dan saling berkaitan antara satu topik dengan topik lainnya.

Dalam matematika terdapat lima kemampuan dasar yang dikemukakan oleh NCTM (2000) yakni pemecahan masalah (problem solving), penalaran dan bukti (reasoning and proof) komunikasi (communication), koneksi (connection) dan representasi (representation). Koneksi merupakan salah satu dari lima 
kemampuan dasar tersebut. Romli (2016:147) mengemukakan bahwa koneksi matematis adalah kemampuan subjek menggunakan keterkaitan ide-ide dalam matematika dan mengaplikasikan ide-ide matematika dalam konteks di luar matematika. Kemampuan koneksi penting dimiliki oleh siswa agar mereka mampu menghubungkan antara materi yang satu dengan materi yang lainnya (Linto,dkk; 2012:83). Sebagaimana diungkapkan dalam (NCTM,2000:274) tanpa koneksi, siswa harus belajar dan mengingat terlalu banyak konsep terisolasi dan keterampilan. Blum, dkk dalam Mhlolo,dkk (2012) menyatakan bahwa literatur telah mengidentifikasi dua jenis koneksi matematis yang pertama adalah mengenali dan menerapkan matematika untuk konteks di luar matematika (hubungan antara matematika, disiplin ilmu lain atau dunia nyata). Noto, dkk (2016: 101) juga berpendapat koneksi matematis berarti kegiatan menghubungkan antara konsep-konsep matematika; menghubungkan konsep matematika dengan konsep pelajaran lainnya; menerapkan pemikiran dan pemodelan matematika untuk memecahkan masalah yang muncul dalam disiplin lain seperti seni, musik, psikologi, sains, dan bisnis; bahkan juga kegiatan menghubungkan konsep matematika dengan kehidupan sehari-hari.

Menurut NCTM (2003) Indikator tentang koneksi matematis meliputi :

a. Mengenali dan menggunakan koneksi antar ide matematis.

b. Mengenali dan menerapkan matematika dalam konteks diluar matematika.

c. Menunjukkan bagaimana gagasan matematika saling berhubungan dan saling membangun satu sama lain untuk menghasilkan keseluruhan yang koheren.

Koneksi matematis berhubungan dengan pemahaman konsep matematika seperti pendapat (Apriyono, 2016:23) yaitu selama siswa melakukan kegiatan koneksi matematis secara berlanjut atau terus menerus (continu), siswa akan melihat bahwa matematika bukan hanya serangkaian pengetahuan konsep yang terpisah, akan tetapi siswa dapat menggunakan pembelajaran di satu konsep matematika untuk memahami konsep matematika yang lainnya.

Dalam Permendikbud nomor 58 tahun 2014 salah satu tujuan dari pembelajaran matematika yaitu dapat memahami konsep matematika. Aspek pemahaman konsep merupakan kompetensi yang ditunjukan peserta didik dalam memahami konsep dan dalam melakukan prosedur (algoritma) secara luwes, akurat, efisien dan tepat (Ariyanto, 2014:29). Siswa dapat memahami konsep matematika yang mereka pelajari karena mereka telah menguasai materi prasyarat yang berkaitan dengan kehidupan sehari-hari (Linto, dkk ;2012:83).

Anderson dalam Dwijayanti (2018:5) Indikator pemahaman konsep meliputi:
a. Menafsirkan
b. Mencontohkan
c. Mengklasifikasi
d. Merangkum
e. Menyimpulkan
f. Membandingkan
g. Menjelaskan 
Menurut Handayani dan Sugiarti (2006:5) konsep gender adalah sifat yang melekat pada kaum laki-laki dan perempuan yang dibentuk oleh faktor-faktor sosial maupun budaya, sehingga lahir beberapa anggapan tentang peran sosial dan budaya laki-laki dan perempuan. penguasaan materi prasyarat . David dan Carr (dalam Apriyono, 2016:24) mengemukakan siswa laki-laki lebih menyukai mendapat informasi dari memori dan menggunakan strategi kognitif seperti dekomposisi, sementara siswa perempuan lebih menyukai menggunakan strategi yang terbuka seperti menghitung jari atau strategi memanipulasi untuk menyelesaikan masalah matematika. Maccoby dan Jacklyn dalam Zubaidah (2013:24) mengatakan laki-laki dan perempuan mempunyai perbedaan kemampuan antara lain sebagai berikut:

1. Perempuan mempunyai kemampuan verbal lebih tinggi daripada laki-laki

2. Laki-laki lebih unggul dalam kemampuan spasial (penglihatan keruangan) daripada perempuan

3. Laki-laki lebih unggul dalam kemampuan matematika.

Zubaidah (2013:15) menyatakan perbedaan gender tentu menyebabkan perbedaan fisiologi dan memengaruhi perbedaan psikologis dalam belajar. Sehingga siswa laki-laki dan perempuan tentu memiliki banyak perbedaan dalam mempelajari matematika.

\section{METODE PENELITIAN}

Penelitian ini menggunakan metode penelitian deskriptif kualitatif, dengan subjek yaitu siswa kelas VII semester genap MTs Negeri 1 Kudus tahun 2017/2018. Subjek dalam penelitian ini yaitu 3 siswa laki-laki dan 3 siswa perempuan yang mempunyai kemampuan setara yaitu kategori sedang. Pemilihan subjek diambil dari nilai ulangan harian materi yang sudah diajarkan yang nilainya masuk dalam kategori sedang dengan mempertimbangkan usulan dari guru matematika yang mengajar.

Instrumen dalam penelitian ini yaitu : instrumen utama adalah peneliti sendiri karena penelitian ini merupakan penelitian kualitatif. Kedudukan peneliti disini sebagai perencana, pelaksana pengumpulan data, analisis, penafsir data, dan pada akhirnya ia menjadi pelapor hasil penelitiannya (Moleong, 2013:168). Instrumen pendukung yaitu tes tertulis berupa soal uraian tentang pemahaman konsep matematika dan tes wawancara berupa tes kemampuan koneksi matematis siswa.

Teknik pengumpulan data pada penelitian ini yaitu

1. Dokumentasi

Dokumentasi dalam penelitian ini berupa daftar nama siswa dan data nilai ulangan harian siswa pada materi yang telah diajarkan oleh guru, yang nantinya akan dipilih beberapa siswa untuk dijadikan sebagai subjek penelitian.

2. Tes Tertulis

Tes tertulis yang digunakan dalam penelitian ini yaitu berupa tes uraian yang memuat tujuh indikator tes pemahaman konsep matematika.

3. Wawancara 
Wawancara dalam penelitian ini digunakan untuk mengetahui koneksi matematis siswa dalam memahami konsep matematika yang sudah dikerjakan subjek pada tes tertulis.

Keabsahan data menggunakan triangulasi sumber yaitu membandingkan informasi yang diperoleh dari sumber yang berbeda. Teknik analisis data dilakukan dengan tiga tahapan yaitu : reduksi data, penyajian data, dan penarikan kesimpulan. Tes tertulis yang diberikan berupa tes pemahaman konsep matematika dan tes wawancara berupa tes kemampuan koneksi matematis siswa yang sudah divalidasi oleh ahli.

\section{HASIL DAN PEMBAHASAN}

Dalam penelitian ini, dilakukan tes tertulis untuk mengetahui pemahaman konsep matematika dan tes wawancara untuk mengetahui koneksi matematisnya. Tes pemahaman konsep matematika memuat indikator menafsirkan, mencontohkan, mengklasifikasi, merangkum, menyimpulkan, membandingkan, dan menjelaskan. Contoh sooa tes tertulis terdapat pada gambar 1. Hasil tes tertulis dan wawancara subjek laki-laki dapat dilihat pada gambar 2 dan gambar 3 . Sedangkan contoh hasil tes tertulis dan wawancara pada subjek perempuan dapat dilihat pada gambar 4 dan gambar 5

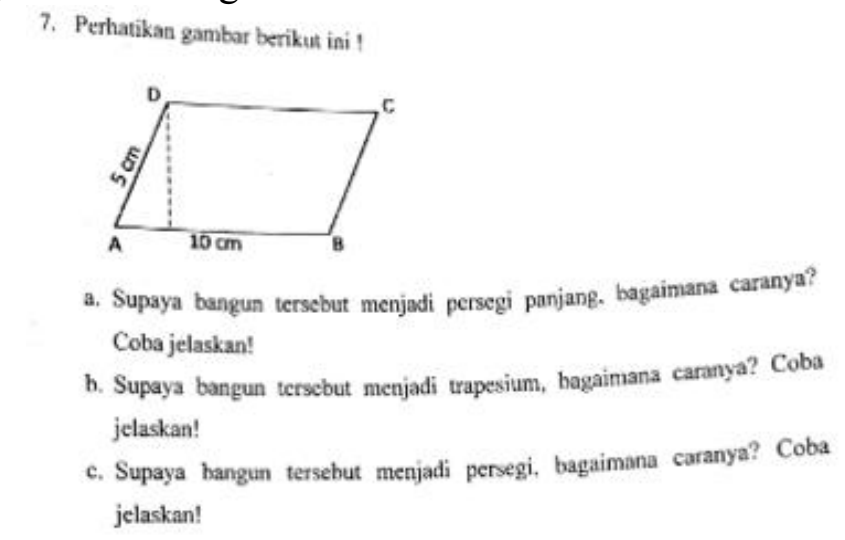

Gambar 1. Contoh soal tertulis

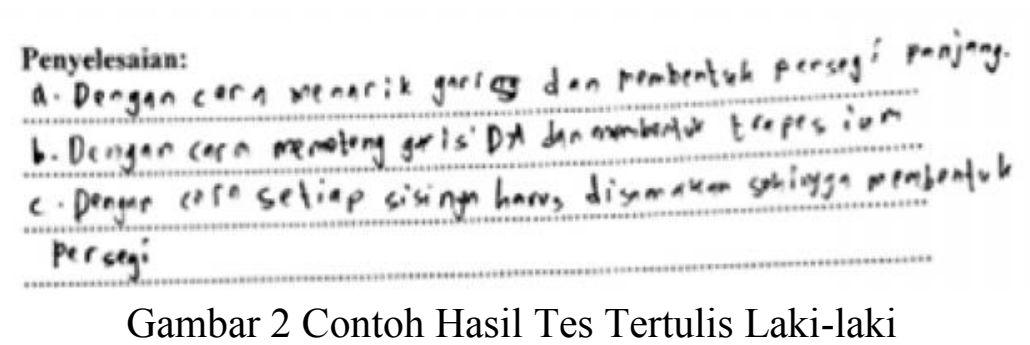

Dari hasil tes tertulis dan wawancara diperoleh hasil berikut: Pada tahap menafsirkan, siswa laki-laki menafsirkan pernyataan tersebut dengan menggambar persegi dan memotong dari sudut kesudut. Siswa laki-laki 
menggambar sudut tegak lurus yaitu $90^{\circ}$ dengan keempat sisinya sama sehingga menjadi bentuk persegi. Pada tahap ini siswa laki-laki menafsirkan pernyataan tersebut menjadi sebuah persegi dengan melihat bahwa panjang keempat sisinya sama.

Pada tahap mencontohkan, siswa laki-laki mecontohkan dari masingmasing bangun segiempat. Siswa laki-laki juga mencontohkan yang bukan segiempat. Siswa laki-laki mencontohkan bangun tersebut dengan melihat bendabenda yang ada disekitarnya. Namun siswa laki-laki tidak menyebutkan contoh lagi selain yang sudah disebutkan.

Pada tahap mengklasifikasikan, siswa laki-laki menggolongkan benda yang termasuk segiempat dan bukan segiempat. Pada tahap tersebut siswa lakilaki mengklasifikasikan bangun segiempat dan bukan segiempat dari jumlah sisinya. Jika benda yang sisinya ada empat maka termasuk segiempat dan jika benda yang sisinya tidak empat maka termasuk bukan segiempat.

Pada tahap merangkum, siswa laki-laki merangkum ciri-ciri dari masingmasing bangun segiempat dari sisinya. Namun ada sebagian bangun segiempat yang disebutkan berkaitan dengan sudut. Pada tahap tersebut, siswa laki-laki merangkum dari yang diingatnya di buku. Selain itu subjek juga melihat dari bentuk bangun tersebut.

Pada tahap menyimpulkan, siswa laki-laki menyimpulkan definisi masingmasing segiempat seperti definisi segiempat secara umum. Pada tahap tersebut siswa laki-laki menyimpulkan dengan melihat ciri-ciri yang sudah disebutkan pada soal sebelumnya. Dengan mengetahui ciri-cirinya, siswa laki-laki menyimpulkan definisi seperti yang sudah ditulis.

Pada tahap membandingkan, siswa laki-laki membandingkan dengan melihat sisinya. Siswa laki-laki menghubungkan persegi panjang dengan jajar genjang yaitu karena sisi yang berhadapan sama panjang tapi sudutnya beda. Siswa laki-laki tidak mengkaitkan dengan materi yang lain.

Pada tahap menjelaskan, siswa laki-laki menjelaskan bahwa perubahan bentuk dari jajar genjang menjadi bangun segiempat yang lain yaitu dengan membuat garis bantu. Pada tahap tersebut, siswa laki-laki menjelaskan dari pikirannya sendiri dengan melihat bentuknya. Siswa laki-laki tidak menemukan cara yang lainnya.

Pada tahap menafsirkan, siswa perempuan menafsirkan pernyataan tersebut dengan menggambar persegi dan memotong dari sudut kesudut. Siswa perempuan menggambar sudut tegak lurus yaitu $90^{\circ}$ dengan keempat sisinya sama sehingga menjadi bentuk persegi. Siswa perempuan menafsirkan menjadi gambar tersebut hanya karena keinginan saja. Siswa perempuan tidak menyebutkan alasan yang logis.

Pada tahap mencontohkan, siswa perempuan menyebutkan contoh dari masing-masing segiempat kecuali jajar genjang dan trapesium. Siswa perempuan juga menyebutkan contoh yang bukan segiempat. Dalam mencontohkan, siswa perempuan melihat benda-benda yang ada disekitarnya. Siswa perempuan juga menyebutkan contoh lainnya selain yang disebutkan yaitu contoh dari persegi panjang dan persegi. 
Pada tahap mengklasifikasikan, siswa perempuan menggolongkan benda yang termasuk segiempat dan bukan segiempat. Siswa perempuan mengklasifikasikan yang termasuk segiempat hanya karena seperti segiempat. Sedangkan yang termasuk bukan segiempat hanya menunjuk benda dan menyebutkan nama benda tersebut. Siswa perempuan tidak memberi alasan yang logis.

Pada tahap merangkum, siswa perempuan merangkum ciri-ciri dari masing-masing bangun segiempat dari sisi dan sudutnya. Namun ada sebagian bangun segiempat yang disebutkan cirinya hanya dari sisi. Pada tahap tersebut, siswa perempuan merangkum dengan mengingat apa yang sudah diajarkan oleh gurunya.

Pada tahap menyimpulkan, siswa perempuan menyimpulkan definisi masing-masing segiempat seperti definisi segiempat secara umum. Pada tahap tersebut siswa perempuan menyimpulkan dengan melihat ciri-ciri yang sudah disebutkan pada soal sebelumnya. Dengan mengetahui ciri-cirinya, siswa perempuan menyimpulkan definisi seperti yang sudah ditulis.

Pada tahap membandingkan, siswa perempuan membandingkan dengan bantuan potongan segitiga. Siswa perempuan menghubungkan persegi panjang dan jajargenjang dengan mengetahui bahwa keempat sisinya sama dan termasuk segiempat. Siswa perempuan mengkaitkan materi tersebut dengan segitiga.

Pada tahap menjelaskan, siswa perempuan menjelaskan bahwa bangun jajar genjang tersebut bisa menjadi bangun segiempat yang lain dengan membuat garis bantu. Pada tahap tersebut, siswa perempuan menjelaskan dengan mengingat yang ada di buku. Siswa perempuan tidak menemukan cara yang lain.

Sesuai dengan pembahasan di atas, perbedaan kemampuan koneksi matematis antara siswa laki - laki dan perempuan dalam memahami konsep matematika dapat dilihat pada tabel 1 .

Tabel 1. Perbedaan kemampuan koneksi matematis siswa laki-laki dan perempuan dalam memahami konsep matematika

\begin{tabular}{|c|c|c|c|c|}
\hline $\begin{array}{c}\text { Indikator } \\
\text { Pemahaman } \\
\text { Konsep } \\
\text { Matematika }\end{array}$ & $\begin{array}{c}\text { Indikator Koneksi } \\
\text { Matematis }\end{array}$ & Siswa laki-laki & Siswa perempuan & $\begin{array}{l}\text { Ada } \\
\text { Perbedaan/ } \\
\text { tidak }\end{array}$ \\
\hline $\begin{array}{l}\text { Menafsirkan } \\
\text { pernyataan yang } \\
\text { berhubungan } \\
\text { dengan segiempat } \\
\text { kedalam bentuk } \\
\text { gambar }\end{array}$ & $\begin{array}{l}\text { Mengenali } \\
\text { dan } \\
\text { menggunaka } \\
\mathrm{n} \text { koneksi } \\
\text { antar ide } \\
\text { matematis }\end{array}$ & \begin{tabular}{lr}
\multicolumn{2}{l}{ Menafsirkan } \\
kedalam & bentuk \\
gambar & persegi \\
karena & semua \\
sisinya & sama \\
panjang &
\end{tabular} & \begin{tabular}{lr}
\multicolumn{2}{l}{ Menafsirkan } \\
kedalam bentuk \\
gambar persegi \\
hanya \\
hanya \\
$\begin{array}{l}\text { saja } \\
\text { sanginan }\end{array}$
\end{tabular} & $\begin{array}{l}\text { Ada } \\
\text { perbedaa } \\
n\end{array}$ \\
\hline $\begin{array}{l}\text { Mencontohkan } \\
\text { permukaan benda } \\
\text { berbentuk } \\
\text { segiempat dan } \\
\text { bukan segiempat }\end{array}$ & $\begin{array}{l}\text { Mengenali } \\
\text { dan } \\
\text { menerapkan } \\
\text { matematika } \\
\text { dalam } \\
\text { konteks } \\
\text { diluar } \\
\text { matematika. }\end{array}$ & $\begin{array}{l}\text { Mencontohkan } \\
\text { dengan melihat } \\
\text { benda sekitar }\end{array}$ & $\begin{array}{l}\text { Mencontohkan } \\
\text { dengan melihat } \\
\text { benda sekitar }\end{array}$ & $\begin{array}{l}\text { Tidak ada } \\
\text { perbedaa } \\
\text { n }\end{array}$ \\
\hline
\end{tabular}




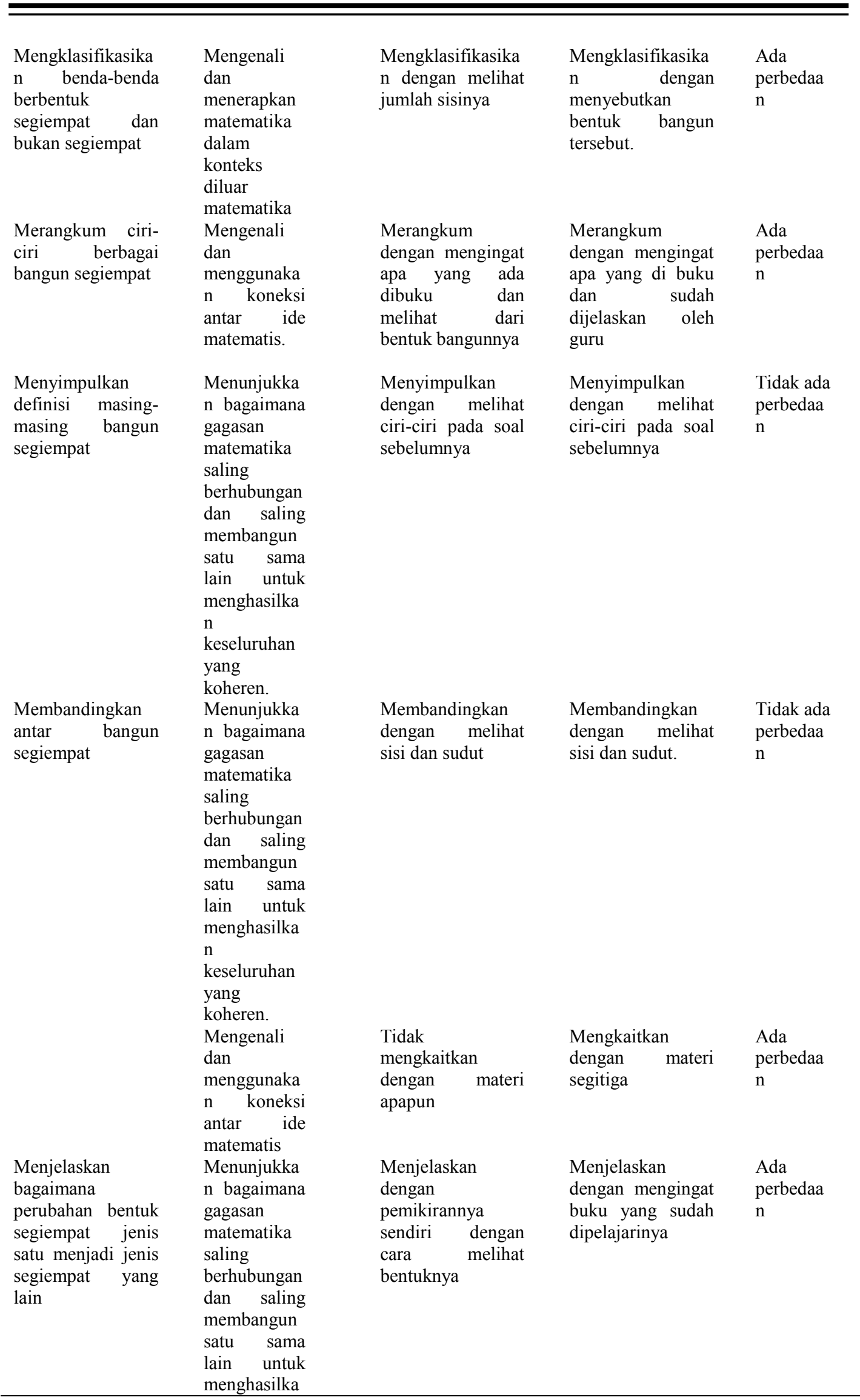




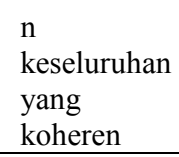

Berdasarkan tabel 1, pada tahap mencontohkan, siswa laki-laki dan perempuan mencontohkan dengan mengkoneksikan matematika melalui benda sekitarnya. Itu sama halnya mereka menghubungkan matematika dengan dunia nyata. Seperti pendapat Blum, dkk (dalam Mhlolo dkk, 2012) yang mengatakan bahwa koneksi matematis yang pertama adalah mengenali dan menerapkan matematika untuk konteks diluar matematika ( hubungan antara matematika, disiplin ilmu lain atau dunia maya).

Pada tahap mengklasifikasi benda-benda yang ada pada kehidupan seharihari, siswa laki-laki mampu mengkoneksikan matematika yaitu dengan melihat jumlah pada sisi. Jika sisinya empat maka termasuk segiempat dan jika sisinya tidak empat maka termasuk bukan segiempat. Hal tersebut sesuai pendapat Noto ,dkk (2016: 101) yaitu koneksi matematis berarti juga kegiatan menghubungkan konsep matematika dengan kehidupan sehari-hari. Namun pada siswa perempuan, hanya menyebutkan bentuk bangunnya.

Pada tahap merangkum, siswa laki-laki dan perempuan mengkoneksikan matematika dengan mengingat apa yang ada di buku. Hal tersebut menunjukkan kurangnya kemampuan koneksi matematika yaitu sesuai dengan pendapat (NCTM, 2000 :274) tanpa koneksi, siswa harus belajar dan mengingat terlalu banyak konsep terisolasi dan keterampilan. Namun siswa laki-laki juga mengkoneksikan dengan melihat bentuk bangunnya. Seperti halnya Pada tahap menjelaskan, siswa laki-laki mampu mengkoneksikan matematika yaitu dengan menjelaskan cara agar terbentuk bangun lain dengan pemikirannya sendiri melalui melihat bentuknya. Hal tersebut sesuai dengan pendapat Maccoby dan Jacklyn dalam Zubaidah (2013:24) yang mengatakan bahwa Laki-laki lebih unggul dalam kemampuan spasial (penglihatan keruangan) daripada perempuan.

Pada tahap menyimpulkan, siswa laki-laki dan perempuan keduanya mengkoneksikan matematika dengan mengetahui ciri-ciri yang sudah ada pada sebelumnya. Hal tersebut sesuai dengan pendapat Noto, dkk (2016 : 101) yang mengatakan bahwa koneksi matematis berarti kegiatan menghubungkan konsepkonsep matematika.

Pada tahap membandingkan, siswa laki-laki tidak mengkaitkan dengan materi lainnya. Hal tersebut sesuai dengan pendapat (Linto, dkk ; 2012 : 83) kemampuan koneksi penting dimiliki oleh siswa agar mereka mampu menghubungkan antara materi yang satu dengan materi yang lainnya.

Dari pembahasan diatas terlihat banyak perbedaan antara laki-laki dan perempuan dalam mengkoneksikan matematika sama halnya mempelajari matematika. Hal tersebut sesuai dengan pendapat (Zubaidah, 2013 : 15) yang mengatakan bahwa perbedaan gender tentu menyebabkan perbedaan fisiologi dan memengaruhi perbedaan psikologis belajar. Sehingga siswa laki-laki dan perempuan tentu memiliki banyak perbedaan dalam mempelajari matematika. 


\section{SIMPULAN DAN SARAN \\ Simpulan}

Berdasarkan hasil penelitian dan pembahasan yang telah dilakukan peneliti mengenai profil kemampuan koneksi matematis siswa dalam memahami konsep matematika ditinjau dari gender dengan subjek kelas VII, maka dapat disimpulkan sebagai berikut : a) Profil kemampuan koneksi matematis siswa lakilaki dalam memahami konsep matematika yaitu pada tahap menafsirkan, siswa laki-laki menafsirkan dengan melihat panjang sisinya. Pada tahap mencontohkan, siswa laki-laki melihat benda sekitar. Pada tahap mengklasifikasikan, siswa lakilaki melihat jumlah sisinya. Pada tahap merangkum, siswa laki-laki mengingat yang di buku dan melihat bentuknya. Pada tahap menyimpulkan, siswa laki-laki mengkoneksikan dengan ciri-ciri. Pada tahap membandingkan, siswa laki-laki melihat sisi dan sudutnya, namun tidak mampu mengkaitkan dengan materi lain. Pada tahap menjelaskan, siswa laki-laki menjelaskan dengan pemikiran sendiri dengan melihat bentuknya. b) Profil kemampuan koneksi matematis siswa perempuan dalam memahami konsep matematika yaitu pada tahap menafsirkan, siswa perempuan menafsirkan gambar karena keinginan saja. Pada tahap mencontohkan, siswa perempuan melihat benda sekitar. Pada tahap mengklasifikasikan, siswa perempuan hanya menyebutkan nama benda tersebut. Pada tahap merangkum, siswa perempuan mengingat yang di buku dan yang diajarkan guru. Pada tahap menyimpulkan, siswa perempuan mengkoneksikan dengan ciri-ciri. Pada tahap membandingkan, siswa perempuan melihat sisi dan sudut dan juga mengkaitkan dengan materi lain namun belum tepat. Pada tahap menjelaskan, siswa perempuan mengingat yang ada di buku.

\section{Saran}

Berdasarkan hasil penelitian yang penulis peroleh, maka dikemukakan saran - saran sebagai berikut:

1. Siswa laki-laki dan perempuan menunjukkan perbedaan pada kemampuan koneksi matematisnya dalam memahami konsep matematika.

2. Kemampuan koneksi matematis dalam memahami konsep matematika masih kurang. Untuk itu sebaiknya guru lebih bisa mengajak siswa untuk mengeksplor apa yang dilihat dan diketahuinya.

3. Diharapkan ada penelitian selanjutnya untuk mengetahui mengapa kemampuan koneksi matematis siswa dalam memahami konsep matematika masih kurang.

\section{DAFTAR PUSTAKA}

Amir, Z. (2013). Perspektif Gender dalam Pembelajaran Matematika. Jurnal Marwah, 12 (1), 14-31.

Apriyono, F. (2016). Profil kemampuan Koneksi Matematika Siswa SMP dalam Memecahkan Masalah Matematika Ditinjau dari Gender. Jurnal Pendidikan Matematika STKIP Garut, 8(3), 22-31.

Ariyanto, L. dkk. (2014). Implementasi Animasi Matematika dengan Pendekatan Realistic Mathematics Education untuk Meningkatkan Pemahaman Matematis Siswa Sekolah Dasar. Journal Aksioma UPGRIS. 5(1).26-34.

Dwijayanti, I. (2018). Student Mathematical Imagination Instrumen Construction, Cultural Adaption and Validity. Journal of Physics : conference Series 983. 
Handayani, T. dan Sugiarti. (2006). Konsep dan Teknik Penelitian Gender. Malang: UMM Press.

Lapp, D.A. dkk. (2010). Student Connections of Linear Algebra Concepts: An Analysis of Concept Maps. International Journal of Mathematical Education in Science and Technology.41(1),1-18.

Linto, R. L. dkk. (2012). Kemampuan Koneksi Matematis dan Metode Pembelajaran Quantum Teaching dengan Peta Pikiran. Jurnal Pendidikan Matematika , l(1), 83-87.

Mhlolo, dkk. (2012). The Nature and Quality Of the Mathematical Connections Teachers Make. Pythagoras,33(1),1-9.

Miles, M.T. dan Huberman, A.M. (Ed.). (2014). Analisis Data Kualitatif. Jakarta:UI Press.

Moleong, L. (2013). Metodologi Penelitian Kualitatif. Bandung: PT Remaja Rosdakarya.

National Council of Teacher of Mathematics (NCTM). (2000). Principles and Standars for School Mathematics. Reston, VA:NCTM.

National Council of Teacher o Mathematics (NCTM). (2003). Programs For Initial Preparation of Mathematics Teachers. Reston, VA:NCTM.

Noto, M.S. dkk. (2016). Analysis of Students Mathematical Representation and Connection on Analytical Geometry Subject. Journal of Mathematics Education, 5(2),99-108.

Peraturan Menteri Pendidikan dan Keudayaan Republik Indonesia Nomor 58 Tahun 2014 Tentang Kurikulum 2013 SMP/MTs. Kementrian Pendidikan dan Kebudayaan.

Romli, M. (2016). Profil Koneksi Matematis Siswa Perempuan SMA dengan Kemampuan Matematika Tinggi dalam Menyelesaikan Masalah Matematika. Jurnal Ilmiah Pendidikan Matematika, 1(2), 145-157. 